УДК [37.041:004.73]:687.01

Kalina L. Pashkevich

Doctor of Engineering Science, Professor,

Professor of the Department of Ergonomics and Fashion Designing

Kyiv National University of Technologies and Design, Kyiv, Ukraine

ORCID ID 0000-0001-6760-3728

pashkevich.kl@knutd.edu.ua

Olga V. Yezhova

Doctor of Pedagogical Sciences, Professor, Professor of the Department of Theory and Methods of Technological Training, Professional Labour and Life Safety

Volodymyr Vynnychenko Central Ukrainian State Pedagogical University, Kropyvnytskyi, Ukraine

ORCID ID 0000-0002-5920-1611

oyezhova@gmail.com

Olena D. Gerasymenko

Postgraduate Student of the Department of Ergonomics and Fashion Designing

Kyiv National University of Technologies and Design, Kyiv, Ukraine

ORCID ID 0000-0001-8566-7215

gerasymenko.od@knutd.edu.ua

\title{
USE OF INFORMATION AND COMMUNICATION TECHNOLOGIES FOR ORGANIZING SELF-EDUCATION OF PERSONALITY IN THE FIELD OF CLOTHES DESIGN
}

\begin{abstract}
The article considers the following aspects of organization of self-education using the information and communication technologies (ICTs): what information resources can be the basis for self-education; how to organize the education; how to solidify the acquired knowledge and create necessary social connections. The information resources which can be used for selfeducation and their classification depending on the needs of the individual - for personal enrichment or for scientific search, - are determined; the most significant among them are electronic libraries and bibliographic and abstract databases. The ways of organization of selfeducation are analyzed, namely: massive online courses, educational applications for PCs and mobile phones, individual classes (webinars), consistent self-development of separate topics, etc. ICTs that promote the creation of social connections and communications with like-minded people and specialists with narrow focus (social networks, scientists' identification systems, forums and blogs) are considered. The examples of information recourses, aimed at obtaining professionally important information by fashion designers, are provided. Among them are blogs about art, fashion and design, virtual museum sites, resources for fashion industry leaders, sites of exhibitions, contests, popular and scientific journals, designers and brands. The possibilities of assessing the reliability of scientific information using the bibliographic and abstract databases, social networks and individual profiles of scientists in the systems of identification are determined. In order to identify the specifics of ICTs use, a questionnaire survey has been conducted that has outlined the main informational resources used in the search for the necessary information (encyclopedias and databases, social networks, YouTube channels and blogs in Twitter, LifeJournal, etc.), and peculiarities of perception of such information. It is found that ICTs are the main source for searching and receiving information.
\end{abstract}

Keywords: self-education; information and communication technologies (ICTs); information resources; social networks; design of the clothes.

\section{INTRODUCTION}

Statement of the problem. The increase of the information in all areas of human activity and the development of information and communication technologies lead to the growing role of self-education and expanding prospects for the realization of self-education 
potential. The use of ICTs provides an opportunity to learn new knowledge, to be inspired by new ideas, to communicate better with professionals from various industries, and to develop skills and competencies - all in accessible form and at a convenient time. The use of ICTs to find the necessary information, as well as to ensure the feedback from both manufacturers and consumers in the field of clothes design, becomes more and more important. Thus, the organization of the process of self-education using ICTs when a person is very busy and does not have enough free time is a topical issue.

Analysis of the recent researches and publications. The problem of self-education has been under consideration of different scientists; they consider it in the context of concrete historical types of cultures [1], as a condition for capacity-building of professional self-development [2], and explore the principles of professional self-development of university lecturers [3].

T. V. Topchyi defines a continuous education as a systemic environment for the formation of personality, which provides maximum self-development and self-realization [4]. N. O. Terokhina emphasizes the role and significance of informal education as an important component of life-long education among the formal, informal and self-education components of continuous education [5]. The peculiarities of organization and prospective directions of development of informal education in Ukraine are analyzed in [6]. The authors [7] state that informal education and self-education are identical concepts, and consider social networks as their main instrument. Functional possibilities of the services of electronic social networks for their application in educational, professional, personal and social activities of an individual are analyzed by O. E. Konevshchynska and S. G. Lytvynova [8]. The questions of people's interaction in social networks, as well as the peculiarities of formation of new social connections are considered by J. Kleinberg in his article [9].

A. M. Mytko notes that "the application of multimedia and ICTs provides an opportunity to increase the intensity and effectiveness of the learning process, creates the conditions for selfeducation and distance education, thereby allowing the transition to continuous education and, in combination with telecommunication technologies, solves the problem of the access to the new sources of information, diverse in content and in form of presentation" [10]. The use of ICTs in educational institutions offers new opportunities for those who are studying: the flexibility of the scientific agenda - the student can choose the courses, teachers, time of active work, etc.; individualization of the learning process, depending on the psychophysiological capabilities of the students, and the provision of equal opportunities for both ordinary people and people with disabilities [11]. Y. N. Shutenko determines as the space for the use of ICTs not only the scope of didactic programs and techniques, but also the display area of the different forms of selfrealization of the students, which increases their abilities to gain the experience of self-changes and to facilitate the transition of external content into the internal one with its subsequent explication in the activity [12].

In the article [13], as a result of the comparative analysis of the models of training of the fashion industry specialists in different countries, it is determined that in all leading world fashion schools considerable attention is paid to the application of information and communication technologies in the design of clothes, in particular, in the independent work of the students on the creation of their own collections. The modern information technologies and the methods of their application in the training of the clothing design specialists [14], as well as the peculiarities of formation of ICT-competencies of the garment industry specialists [15] have been researched.

The author [16] analyzes the possibilities for using the G Suite for Education Services (Gmail, Google Drive, Google Forms, Google Documents, Google Spreadsheets, etc.) in the learning process. R. L. Soichuk in the article defines the leading directions, peculiarities and prospects of the use of ICTs in educational practice [17]. C. Latchem in his work [18] considers the problem of ICTs integration in the teachers' activities. 
The actual status of application of information and communication technologies and Internet resources for self-education and self-development of personality are analyzed by I. S. Pichuhina [19], H. A. Dehtiarova [20]; the peculiarities of self-education in the conditions of the modern informational and educational environment are distinguished by O. V. Kyselyova [21]. The authors [22] have analyzed how the different types of e-learning systems affect the learning experience and its effectiveness.

The purpose of the article. The aim is to identify the possibilities of using information and communication technologies to ensure effective organization of self-education of an individual in the field of clothes design.

\section{RESULTS OF THE RESEARCH}

In order to organize an effective process of self-education, it is necessary to start any training with the understanding of the reasons why it is necessary. Understanding the need for certain knowledge and outlining its goal help a person to set certain objectives (studying of a specific issue, mastering of the skill, or obtaining a document that confirms the obtained competency) and to determine the desired results. Accordingly, a search for the possible ways of organization of self-education is carried out by solving the following problems:

- what will be the basis for education, what information resources;

- where and in what way self-educational potential will be realized, how to organize the education;

- how to solidify the obtained knowledge, to create necessary physiological, mental and social connections.

The rapid development of information and communication technologies (ICTs) has expanded opportunities for solving the stated problem and realization of self-education potential.

Information resources. The reason for self-education of an individual is the contradiction between the need for activities and the lack of information about the object and the subject of the activity [1]. For a long time, the main sources of such necessary information were only books and personal communication, for which it was necessary to attend lectures, libraries, etc. The prospects of self-education depended on the physical access to the source of information. The development of ICTs, in particular the fourth generation of portable (mobile) 4G radio, provides an access to the information from many sources any time and anywhere, so today the volume and the quality of the knowledge gained depend on the ability to use these technologies.

All known sources of information can be divided into: search systems, online encyclopedias, electronic libraries and abstract and bibliographic databases, publishing and magazine websites, internet portals, content sites, social networks, channels on video hosts, blogs, etc. It is determined that depending on the needs of the individual - for personal enrichment or for scientific search - universal or scientific information resources are used, the classification of which is presented in Table 1.

Among all search systems, according to the needs, we can select specialized systems, such as Google Scholar, PubMed, and universal systems, such as Google, Bing, Yahoo!, etc. Online encyclopedias are popular, for example, multilingual Wikipedia, which is written by the users and needs to be checked, scientific - for example, Scholarpedia, all articles of which are written by the experts, and electronic versions of printed materials (for example, Britannica, Columbia Encyclopedia). A universal source of information is electronic libraries - digital analogues of classic libraries, and the source of scientific information is bibliographic and abstract databases. For example, the Directory of Open Access Journals contains journals in various fields of knowledge; ScienceDirect presents scientific research, owned by Elsevier publishers; PubMed provides an access to materials on specific topics - 
medical and biological publications. Particular attention should be paid to the Scopus platform, which is one of the components of the integrated SciVerse Scientific and Information Environment, as well as to the Web of Science platform, owned by Clarivate Analytics Company. They provide access to scientific information with the ability to track the citation of publication, to review the profiles of the authors and institutions, to compare the data of the different publishers.

Table 1

\section{Information resources for self-education of an individual}

\begin{tabular}{|c|c|c|c|}
\hline \multicolumn{2}{|c|}{ Cross-functional resources } & \multicolumn{2}{|c|}{ Scientific resources } \\
\hline $\begin{array}{c}\text { Name and web-address of } \\
\text { the resource }\end{array}$ & $\begin{array}{l}\text { Description of the } \\
\text { resource }\end{array}$ & $\begin{array}{l}\text { Name and web- } \\
\text { address of the } \\
\text { resource }\end{array}$ & Description of the resource \\
\hline \multicolumn{4}{|c|}{ Search systems } \\
\hline $\begin{array}{l}\text { Google } \\
\text { https://www.google.com.ua }\end{array}$ & \multirow[t]{3}{*}{ Search services } & $\begin{array}{l}\text { Google Academy } \\
\text { (Google Scholar) } \\
\text { https://scholar.goog } \\
\text { le.com.ua }\end{array}$ & $\begin{array}{l}\text { Free available search system that } \\
\text { indexes the full text of scientific } \\
\text { publications from various } \\
\text { disciplines }\end{array}$ \\
\hline Bing https://www.bing.com & & $\begin{array}{l}\text { PubMed } \\
\text { https://www.pubme } \\
\text { d.gov }\end{array}$ & $\begin{array}{l}\text { Search system that offers an } \\
\text { access to the MEDLINE } \\
\text { Database, which contains the }\end{array}$ \\
\hline $\begin{array}{l}\text { Yahoo! } \\
\text { https://www.yahoo.com }\end{array}$ & & & $\begin{array}{l}\text { links and abstracts of the articles } \\
\text { from biomedical magazines }\end{array}$ \\
\hline \multicolumn{4}{|c|}{ Online Encyclopedias } \\
\hline $\begin{array}{l}\text { Wikipedia } \\
\text { https://www.wikipedia.org }\end{array}$ & $\begin{array}{l}\text { Free encyclopedia, } \\
\text { the articles of which } \\
\text { can be edited by } \\
\text { everyone }\end{array}$ & \multirow[t]{3}{*}{$\begin{array}{l}\text { Scholarpedia } \\
\text { http://www.scholar } \\
\text { pedia.org }\end{array}$} & \multirow{3}{*}{$\begin{array}{l}\text { Encyclopedia on the Internet, the } \\
\text { articles of which are written by } \\
\text { scientists and experts in the } \\
\text { relevant subject area and undergo } \\
\text { mandatory review }\end{array}$} \\
\hline $\begin{array}{l}\text { Britannica (Latin: } \\
\text { Encyclopædia Britannica) } \\
\text { https://www.britannica.com }\end{array}$ & \multirow[t]{2}{*}{$\begin{array}{l}\text { Electronic versions of } \\
\text { cross-functional } \\
\text { printed encyclopedias } \\
\text { in English }\end{array}$} & & \\
\hline $\begin{array}{l}\text { World Book Encyclopedia } \\
\text { https://international.worldbo } \\
\text { ok.com }\end{array}$ & & & \\
\hline \multicolumn{4}{|c|}{ Bibliographic and abstract databases } \\
\hline $\begin{array}{l}\text { World Digital Library } \\
\text { https://www.wdl.org }\end{array}$ & $\begin{array}{l}\text { The World Digital } \\
\text { Library, initiated to } \\
\text { promote international } \\
\text { and intercultural } \\
\text { understanding }\end{array}$ & $\begin{array}{l}\text { Scopus } \\
\text { https://www.scopus } \\
\text {.com }\end{array}$ & $\begin{array}{l}\text { Bibliographic and abstract } \\
\text { database, one of the components } \\
\text { of the integrated SciVerse } \\
\text { Scientific and Information } \\
\text { Environment }\end{array}$ \\
\hline $\begin{array}{l}\text { The Library of USA } \\
\text { Congress } \\
\text { https://www.loc.gov }\end{array}$ & $\begin{array}{l}\text { Site of the National } \\
\text { Library of the USA, } \\
\text { the biggest library in } \\
\text { the world that } \\
\text { contains digitized } \\
\text { materials }\end{array}$ & $\begin{array}{l}\text { Web of Science } \\
\text { https://clarivate.co } \\
\text { m/products/web-of- } \\
\text { science }\end{array}$ & $\begin{array}{l}\text { Scientometrical, abstract, } \\
\text { international database, owned by } \\
\text { Clarivate Analytics company }\end{array}$ \\
\hline \multirow[t]{2}{*}{$\begin{array}{l}\text { Open Library } \\
\text { https://openlibrary.org }\end{array}$} & $\begin{array}{l}\text { Electronic library of } \\
\text { digitized books (open } \\
\text { source) }\end{array}$ & $\begin{array}{l}\text { Directory of Open } \\
\text { Access Journals } \\
\text { https://doaj.org }\end{array}$ & $\begin{array}{l}\text { International multidisciplinary } \\
\text { directory of open access journals }\end{array}$ \\
\hline & & $\begin{array}{l}\text { ScienceDirect } \\
\text { https://wWw.scienc } \\
\text { edirect.com }\end{array}$ & $\begin{array}{l}\text { One of the biggest online } \\
\text { collections of published scientific } \\
\text { researches, owned by Dutch } \\
\text { publishing house Elsevier }\end{array}$ \\
\hline
\end{tabular}




\begin{tabular}{|c|c|c|c|}
\hline & & $\begin{array}{l}\text { PubMed } \\
\text { https://www.pubme } \\
\text { d.gov }\end{array}$ & $\begin{array}{l}\text { Electronic database of medical } \\
\text { and biological publications, where } \\
\text { the abstracts of publications in } \\
\text { English are presented. Search } \\
\text { system }\end{array}$ \\
\hline & & $\begin{array}{l}\text { Index Copernicus } \\
\text { http://www.indexco } \\
\text { pernicus.com }\end{array}$ & $\begin{array}{l}\text { Online scientometrical database } \\
\text { that contains user-supplied } \\
\text { information, including scientific } \\
\text { institutions, printed publications } \\
\text { and projects }\end{array}$ \\
\hline \multicolumn{4}{|c|}{ Publishing houses } \\
\hline $\begin{array}{l}\text { "Family Leisure Club" } \\
\text { ("Club Simeinogo } \\
\text { Dozvillia") } \\
\text { https://www.bookclub.ua }\end{array}$ & $\begin{array}{l}\text { Focused on a wide } \\
\text { audience - among its } \\
\text { publications is } \\
\text { artistic, applied, and } \\
\text { children`s literature }\end{array}$ & $\begin{array}{l}\text { Elsevier } \\
\text { https://www.elsevie } \\
\text { r.com }\end{array}$ & $\begin{array}{l}\text { One of the world`s biggest } \\
\text { publishing companies }\end{array}$ \\
\hline $\begin{array}{l}\text { Vivat } \\
\text { https://vivat-book.com.ua }\end{array}$ & $\begin{array}{l}\text { Specializes in the } \\
\text { publishing of modern } \\
\text { and classic literature, } \\
\text { journalism and } \\
\text { humanitarian } \\
\text { researches, applied } \\
\text { literature, etc. }\end{array}$ & $\begin{array}{l}\text { Publishing house } \\
\text { «Internauka» } \\
\text { https://www.inter- } \\
\text { nauka.com }\end{array}$ & $\begin{array}{l}\text { Specializes in the publishing of } \\
\text { scientific journals, monographs } \\
\text { and manuals. Organizes } \\
\text { international scientific } \\
\text { conferences }\end{array}$ \\
\hline \multicolumn{4}{|c|}{ Sites of the magazines } \\
\hline People https://people.com & $\begin{array}{l}\text { Weekly magazine } \\
\text { about famous people }\end{array}$ & $\begin{array}{l}\text { Nature } \\
\text { https://www.nature. } \\
\text { com }\end{array}$ & $\begin{array}{l}\text { One of the authoritative journals, } \\
\text { publishing research devoted to a } \\
\text { wide range of issues, mainly } \\
\text { related to the natural sciences }\end{array}$ \\
\hline $\begin{array}{l}\text { Cosmopolitan } \\
\text { https://www.cosmo.com.ua }\end{array}$ & $\begin{array}{l}\text { Magazine about } \\
\text { fashion, show, } \\
\text { business, beauty }\end{array}$ & $\begin{array}{l}\text { Science } \\
\text { http://www.science } \\
\text { mag.org }\end{array}$ & $\begin{array}{l}\text { Journal for publication of the } \\
\text { results of research from all fields } \\
\text { of science }\end{array}$ \\
\hline \multicolumn{4}{|c|}{ Social networks } \\
\hline $\begin{array}{l}\text { Facebook } \\
\text { https://www.facebook.com }\end{array}$ & Social network & $\begin{array}{l}\text { LinkedIn } \\
\text { https://www.linkedi } \\
\text { n.com }\end{array}$ & $\begin{array}{l}\text { Social network for finding and } \\
\text { establishing business contacts }\end{array}$ \\
\hline $\begin{array}{l}\text { Instagram } \\
\text { https://www.instagram.com }\end{array}$ & $\begin{array}{l}\text { Social network, } \\
\text { based on photo } \\
\text { sharing }\end{array}$ & $\begin{array}{l}\text { XING } \\
\text { https://www.xing.c } \\
\text { om }\end{array}$ & $\begin{array}{l}\text { Business-oriented social network } \\
\text { for searching and managing } \\
\text { business and personal contacts }\end{array}$ \\
\hline $\begin{array}{l}\text { Pinterest } \\
\text { https://www.pinterest.com }\end{array}$ & Social photo service & $\begin{array}{l}\text { Academia.edu } \\
\text { https://www.acade } \\
\text { mia.edu }\end{array}$ & $\begin{array}{l}\text { Social network for scientists } \\
\text { cooperation }\end{array}$ \\
\hline Twitter https://twitter.com & $\begin{array}{l}\text { Social network, } \\
\text { which is a network of } \\
\text { microblogs }\end{array}$ & & \\
\hline $\begin{array}{l}\text { Google+ } \\
\text { https://plus.google.com }\end{array}$ & $\begin{array}{l}\text { Social network and } \\
\text { identity service }\end{array}$ & & \\
\hline
\end{tabular}

Also there are online magazines that usually cover a wider range of topics than printed media, contain video materials in comparison to printed materials. The examples are the popular People and Cosmopolitan magazines that contain journalistic articles, and well-known Nature and Science journals that publish the results of the research from the various fields of science.

Materials for self-education can be found in text, audio and video formats on information resources of different types: Internet portals (Google, Ukr.net, I.ua, znaj.ua etc.), thematic sites (for example, http://www.historians.in.ua - Ukrainian scientific historical site), 
information channels of various types on video hosting (for example, YouTube), blogs in Twitter, LifeJournal and other blog-platforms, social networking pages (Facebook, Instagram etc.). The presented classification does not contain all available resources, only the main ones.

The use of information resources allows people to study the subject from different points of view, to find the needed information quickly and to verify its authenticity. They need less time to find necessary materials, to process them, and to transform them into their own knowledge.

Organization of education. Self-education activities can be organized in different ways: massive online courses, educational applications for PCs and mobile phones, individual classes (webinars), consistent self-development of separate topics, etc. The advantages of the use of ICTs are not only the opportunities to choose the place of study, but also the time and duration of the class.

Today, an online learning community is actively developing, in particular, massive open online courses are gaining popularity - the Massive open online courses (MOOC) - online courses with large-scale interactive participation and open access through the Internet. In addition to the traditional training materials such as articles, videos and tasks, MOOC provides the possibility to use an online forum for users who help to create a community of students, teachers and other interested parties. It is one of the newest ways of organization of self-education activities, which is actively developing in the world and is designed for students of different levels of training - both novices and experienced professionals.

Coursera, EdX, and Udacity are the examples of MOOCs. FutureLearn and Iversity are also among them - online resources, where world-leading academic institutions, well-known for their academics and research in various fields of knowledge, provide free access to courses with a diverse range of subjects: literature, history, culture and the arts, natural sciences, business and others. Such courses help the development in the professional area not only through the acquisition of new knowledge, but also by taking the experience of lecturers from the leading universities and cultural institutions through videos, articles, quizzes and discussions. For a fee, on some platforms it is possible to get additional services (personal tests, individual video classes, etc.) and certificates of their passing. Among the Ukrainian free platforms for massive online courses, we can name EdEra, Prometheus, where the courses are developed by the lecturers of the Taras Shevchenko National University of Kyiv, the National Technical University of Ukraine "Igor Sikorsky Kyiv Polytechnic Institute", the Kyiv-Mohyla Academy, and other leading institutions of higher education of Ukraine, and also the popular courses of world-famous universities, translated into Ukrainian.

Another way of organization of self-education activities is webinars for several people or individual video classes via the messengers for instant text, video and file messages (Skype, Telegram, Viber, WhatsApp, etc.), which provide real-time communication, and can be a part of online courses or a separate self-educating resource. Educational applications for PCs and mobile phones are popular too, which, besides study of the material, include testing of the user`s knowledge, tracking of their progress, and can have a function of shared use (for example, Duolingo for learning languages).

Creation of social connections. The process of remembering at the biological level consists in the creation and strengthening of connections between the neurons, at the mental level - in understanding how the concepts and ideas are related, and at the social level it is realized in acquaintances and communications. Social networks, different forums and blogs promote the creation of social relations and communications.

There are professional, universal, academic, research and other social networks [23]. Among the online professional networks, the most popular are LinkedIn, XING - aimed to find and establish business contacts and Academia.edu - for cooperation of scientists. Communication in such networks provides an opportunity to get new information in specialized and other areas, to interact with other users in real time and with the help of the 
messages. Facebook social network also provides an opportunity to establish professional contacts and to organize the communities of like-minded people: on the pages of educational institutions, companies, individual pages, etc. The creation of individual scientists profiles in the systems of identification, for example, ORCID, ResearcherID, Google Scholar, etc., which make it possible to identify scientists and to review their scientific works, contributes a lot to the communication of the scientists.

Many sites have blogs, forums and "question-answer" sections, which allow communicating in a networked environment with the owners / managers of information resources, experts, like-minded people, and provide information to a specific request [19]. The creation of a personal blog, site, online questionnaires, topics in social networks allows people to express their own opinion, share experiences, get a feedback, even if the topic is specific and highly-specialized. The links on the Internet have been analyzed and the examples of information resources, which can be used by clothes designers to obtain professionally important information, have been highlighted separately (Table 2). Among them are blogs about art, fashion and design, sites of the virtual museums, resources for the fashion industry leaders, sites of exhibitions, competitions, popular magazines and scientific journals. The sites of the well-known designers and brands, which contain information on the current situation in the fashion industry, are not included in Table 2.

Table 2

Information resources for obtaining professionally important information by the fashion designers

\begin{tabular}{|c|c|}
\hline Name of the source and its web-address & Description \\
\hline $\begin{array}{l}\text { Google Art Project } \\
\text { https://artsandculture.google.com }\end{array}$ & $\begin{array}{l}\text { Online platform for accessing pixel-high resolution images of } \\
\text { artistic works, which are stored in museums - partners of the } \\
\text { initiative. }\end{array}$ \\
\hline $\begin{array}{l}\text { Valentino Garavani Museum } \\
\text { http://valentino-garavani-archives.org }\end{array}$ & Valentino Garavani Virtual Design Museum \\
\hline $\begin{array}{l}\text { vassiliev.online } \\
\text { https://www.vassiliev.online }\end{array}$ & Alexander Vasiliev Virtual Fashion and Style Design \\
\hline $\begin{array}{l}\text { Design Milk } \\
\text { https://design-milk.com }\end{array}$ & Blog dedicated to contemporary art and design \\
\hline $\begin{array}{l}\text { Yatzer } \\
\text { https://www.yatzer.com }\end{array}$ & Blog about art, fashion, design and architecture \\
\hline $\begin{array}{l}\text { Fashion United } \\
\text { https://fashionunited.com }\end{array}$ & $\begin{array}{l}\text { International site. B2B (business to business) fashion industry } \\
\text { platform: news, business community, fashion vacancies }\end{array}$ \\
\hline $\begin{array}{l}\text { The Business of Fashion } \\
\text { https://www.businessoffashion.com }\end{array}$ & $\begin{array}{l}\text { Resource for creators, managers and entrepreneurs of the fashion } \\
\text { industry }\end{array}$ \\
\hline $\begin{array}{l}\text { Ukrainian Fashion Week } \\
\text { http://www.fashionweek.ua }\end{array}$ & Ukrainian Fashion Week Official Website \\
\hline $\begin{array}{l}\text { Pecherski Kashtany } \\
\text { https://www.facebook.com/pecherskie.kashtany }\end{array}$ & $\begin{array}{l}\text { International Competition of Young Designers "Pecherski } \\
\text { Kashtany" }\end{array}$ \\
\hline $\begin{array}{l}\text { Kyiv Fashion } \\
\text { http://www.kyivfashion.kiev.ua }\end{array}$ & $\begin{array}{l}\text { Fashion festival, which combines specialized exhibitions of light } \\
\text { and textile industries }\end{array}$ \\
\hline $\begin{array}{l}\text { Vogue } \\
\text { https://www.vogue.com }\end{array}$ & $\begin{array}{l}\text { Fashion magazine, one of the most influential fashion editions in } \\
\text { the world }\end{array}$ \\
\hline Harper's Bazaar https://www.harpersbazaar.com & American Women`s Fashion Magazine \\
\hline $\begin{array}{l}\text { Communication Arts } \\
\text { https://www.commarts.com }\end{array}$ & $\begin{array}{l}\text { Magazine about visual communications, articles on illustration, } \\
\text { graphic design, typography, advertising, photography and } \\
\text { interactive design topics }\end{array}$ \\
\hline BurdaStyle Ukraine https://burdastyle.ua & $\begin{array}{l}\text { Information source on sewing, needlework, creativity, style and } \\
\text { fashion }\end{array}$ \\
\hline Art and Design http://artdesign.knutd.edu.ua & $\begin{array}{l}\text { Peer-reviewed scientific journal with an open access, which covers } \\
\text { issues of art studies and design }\end{array}$ \\
\hline
\end{tabular}


Assessment of reliability of the information. However, with the development of ICTs, the society and individuals faced the problem of information reliability. Classical education includes attending educational institutions that are the guarantors of the quality of the information provided. Primary responsibility for the information in publications presented in libraries rests with the authors and / or publishers. Using ICTs, a person receives a large volume of information, often of unknown origin and false, so the person needs to check the quality and accuracy of such information personally. In order to assess the reliability of, for example, scientific information, it is recommended, besides getting acquainted with the contents: to check the author's profile and the list of their works; to determine whether the topic is in the field of the author's competence; to analyze the level of the publisher or information resource, where the work is published; to look through the linked sources and check who cited this publication. Analysis of other materials on the same subject enables to determine how relevant and reliable the information is. Hence, the use of ICTs provides opportunities for finding and checking the information.

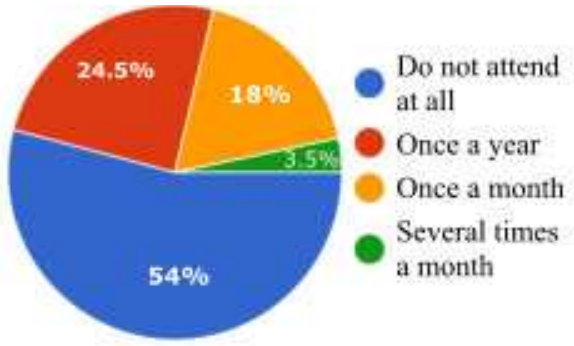

Figure 1. How often do you attend the library?

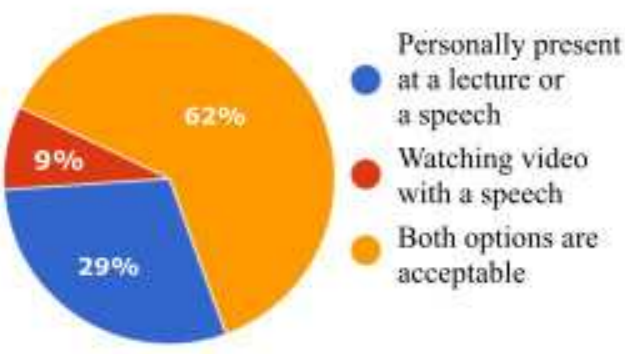

Figure 3. You perceive information better when you...?

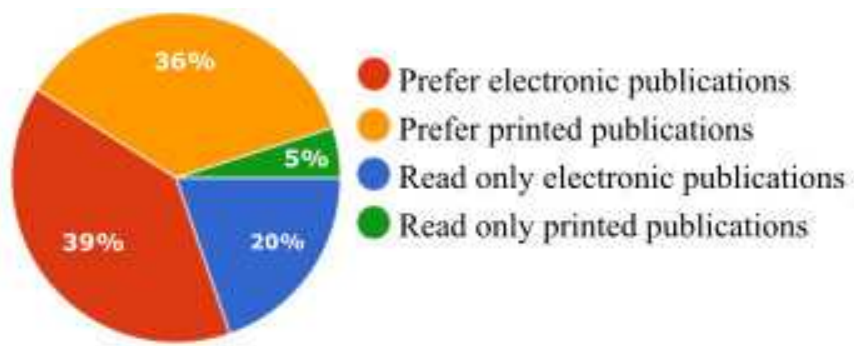

Figure 2. Do you read printed or electronic periodical publications, literature?

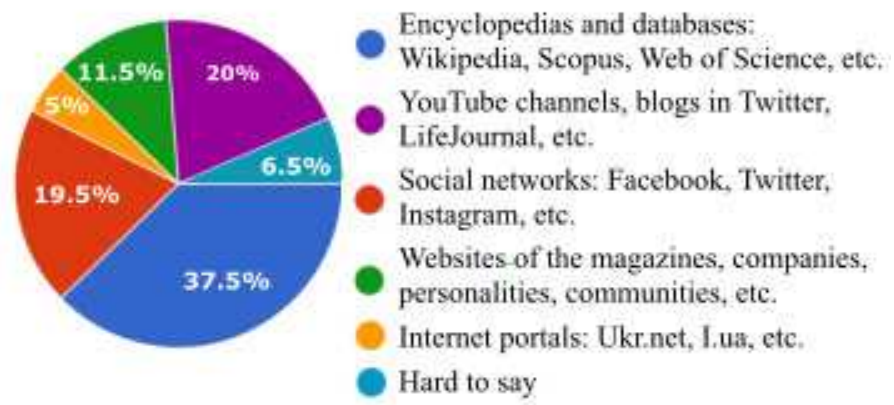

Figure 4. What kind of resources on the Internet is the main source of information for you?

In order to identify the peculiarities of the ICTs use, a survey has been conducted, in which 235 people participated, engaged in studying, science, creativity and production in the field of clothes design, from 18 to 29 years old (78\%) and from 30 to 45 years old (22\%), mostly students $(77 \%)$ and university lecturers $(8 \%)$. The results of the survey show that $54 \%$ of the respondents do not attend libraries at all, and $24.5 \%$ of them visit them once a year (Figure 1). It is identified that $39 \%$ of the respondents prefer electronic publications, $36 \%$ - printed ones, and $20 \%$ - only electronic editions (Figure 2). $42 \%$ of the respondents indicate that they search for the necessary information only on the Internet, the rest of the respondents use all available resources. Thus, it can be argued that ICTs are the main source of information for this particular category of population.

According to the respondents, they can perceive information better when they are personally present at a lecture or a speech $(29 \%)$ or when they watch videos $(9 \%)$, but for most of them $(62 \%)$ both options are acceptable (Figure 3). It is found that $32 \%$ of the 
respondents have never studied at online courses, but among those who have used them, $76 \%$ consider that an online course is a convenient way to gain new knowledge.

The research also shows that the main sources of useful information on the Internet are encyclopedias and databases (37.5\%), YouTube channels and blogs in Twitter, LifeJournal, etc. $(20 \%)$, social networks $(19.5 \%)$, websites of the publishing houses, magazines, companies, personalities, communities $(11.5 \%)$, Internet portals, such as Ukr.net, I.ua, Znaj.ua, etc. (5\%) (Figure 4).

The survey also shows that most respondents visit exhibitions or museums personally (64\%), photographic shows, virtual exhibitions and museums are attended by $16 \%$ and $6.6 \%$ of the respondents respectively.

Based on the data received, we can conclude that in the field of clothes design the ICTs are actively used for self-education and professional development.

\section{CONCLUSIONS AND PROSPECTS FOR FURTHER RESEARCH}

The article presents the results of the research on the possibilities of the use of information and communication technologies for realization of self-educational potential, in particular: for searching of necessary information, organization of self-education activities, establishment of necessary business contacts.

The information resources that can be the source of the information for self-education activities have been analyzed, namely: search systems, online encyclopedias, electronic libraries and abstract and bibliographic databases, publishing and magazine websites, Internet portals, content sites, social networks, channels on video hosts, blogs, etc. It is determined that different information resources can be used depending on the needs of an individual: universal information resources - for personal enrichment, and scientific information resources - for the search of scientific information; their examples are provided. It is defined that the main sources of information are electronic libraries and bibliographic and abstract databases.

Different ways of organization of self-education activities are considered, namely: massive online courses, educational applications for PCs and mobile phones, individual classes (webinars), consistent self-development of separate topics, etc. It is determined that the profiles in social networks and scientists' identification systems ensure the support and development of the connections with like-minded people and with the specialists with narrow focus in different spheres.

An overview of the informational resources for the personal enrichment of the experts in the field of clothes design has been performed and the examples of such resources are presented, namely: blogs about art, fashion and design, virtual museum sites, resources for fashion industry leaders, sites of exhibitions, contests, journals, etc. The variants of assessing the reliability of scientific information using the ICTs are offered.

The peculiarities of the use of ICTs in the field of clothes design are analyzed and it is determined that ICTs are the main source for the search and obtainment of information. The peculiarities of perception of information are revealed, namely, the fact that for most of the respondents it is not important whether they are personally present at a lecture, a speech, or view the recording of an event. It is determined that the respondents consider online courses as a convenient way to gain new knowledge. Also, according to the opinion of the respondents, encyclopedias and data bases are the main sources of useful information on the Internet.

Further research may be aimed at the preparation of methodological recommendations for the organization of the process of self-education, taking into account the possibilities of information and communication technologies. 


\section{REFERENCES (TRANSLATED AND TRANSLITERATED)}

[1] O. V. Burluka, " Self-education of a personality as a social and cultural phenomenon", author's abstract. dis. cand. philosopher. sciences, Kharkiv State Academy of Culture, Kharkiv, 2005. (in Ukrainian)

[2] R. N. Tsokur, " Formation of professional potential of self-development of future teachers in higher educational institutions in the process of master's degree training", author's abstract. dis. cand. pedagogical sciences, SouthUkrainian State Teacher's Training University named after K. D. Ushinsky, Odessa, 2004. (in Ukrainian)

[3] G. G. Tsvetkova, Professional self-improvement of humanitarian disciplines' teachers of higher education, Sloviansk, Ukraine: Vydavnytstvo B. I. Matorina, 2014. (in Ukrainian)

[4] T. V. Topchyi, "The lifelong education as a person forming surrounding are defined", Visnyk Natsionalnoi yurydychnoi akademii Ukrainy imeni Yaroslava Mudroho, № 3, pp. 222-228, 2014. (in Ukrainian)

[5] N. O. Terokhina, "Non-formal education as an important component of adult education", Porivnialnopedahohichni studii, № 6(20), pp. 109-114, 2014. (in Ukrainian)

[6] O. V.Anishchenko, L. B. Lukianova, and S. M. Pryima, "Non-formal adult education - educational trend of the XXI century", Ridna shkola, vol. 11, pp. 3-7, 2017. (in Ukrainian)

[7] G. O. Nesterenko, and O. V. Tyshkova, " Modern social network as an instrument of nonformal education", Hileia, vol. 49 (№7), pp. 451-458, 2011. (in Ukrainian)

[8] O. E. Konevshchynska, and S. G. Lytvynova, "Social networks as a component of modern social media", Information Technologies and Learning Tools, vol. 55, № 5, pp. 42-54, 2016. [Online]. Available: https://journal.iitta.gov.ua/index.php/itlt/article/view/1500. Accessed on: Dec. 02, 2018. (in Ukrainian)

[9] J. Kleinberg, "Analysis of large-scale social and information networks", Philosophical Transactions of the Royal Society A, v. 371, 2013. (in English)

[10] A. M. Mytko, "Application of information and communication technologies in training staff for informational, analytical and political spheres", Information Technologies and Learning Tools, vol. 65, №. 3, pp. 291-303, 2018. [Online]. Available: https://journal.iitta.gov.ua/index.php/itlt/article/view/2004. Accessed on: Dec. 02, 2018. (in Ukrainian)

[11] O. Yu. Burov, "Individual abilities and lifelong learning", Information Technologies and Learning Tools, vol. 55, № 5, pp. 1-11, 2016. [Online]. Available: https://journal.iitta.gov.ua/index.php/itlt/article/view/1487. Accessed on: Dec. 02, 2018. (in English)

[12] E. N. Shutenko, "The concept of student youth's self-realization in the conditions of university training's informatization", Obrazovanie i samorazvitie, №4(46), pp. 9-15, 2015). (in Russian)

[13] O. V. Yezhova, K. L. Pashkevich, and N. V. Manoilenko, "Comparative analysis of foreign models of fashion education", Revista Romaneasca pentru Educatie Multidimensionala, vol. 10, Is. 2, pp: 88-101, 2018. doi: https://doi.org/10.18662/rrem/48. (in English)

[14] M. V. Kolosnichenko, K. L. Pashkevych, and N. V. Ostapenko, "Information technologies of teaching - path to preparation of competitive specialists of design of clothes", Bulletin of Kyiv national university of technologies and design: the materials of $V$ Intern. scientific-practical conf. The effectiveness of the organizational and economic mechanism innovative development of higher education in Ukraine", Oct 2., 2015 - special issue Series: Economics, Kyiv, pp. 182-188, 2015. (in Ukrainian)

[15] O. V. Yezhova, "Formation of information and communication technologies' competence of future specialists in the clothing industry using tools of CAD Gracia", Obrazovatel'nye tehnologii i obshhestvo, vol. 18, № 3, pp. 410-420, 2015. [Online]. Available: https://cyberleninka.ru/article/n/formirovaniya-ikt-kompetentsiibuduschih-spetsialistov-shveynoy-otrasli-sredstvami-sapr-gratsiya. Accessed on: Dec. 02, 2018. (in Russian)

[16] I. I. Podik, "The implementation of google services for teaching generation z students", Information Technologies and Learning Tools, vol. 60, №4, pp. 264-274, 2017. [Online]. Available: https://journal.iitta.gov.ua/index.php/itlt/article/view/1770. Accessed on: Dec. 02, 2018. (in Ukrainian)

[17] R. L. Soichuk, "Information and communication technologies in the educational process and the contemporary growing generation: a viewpoint on the problem", Innovatyka u vykhovanni, №4, pp. 220-230, 2016. (in Ukrainian)

[18] C. Latchem "21st century learning, technology and the professional development of teachers", Education and Self Development, Vol. 13, no. 1, pp. 10-18, 2018. (in English)

[19] I. S. Pichuhina, "The current state of application of information and communication technologies for selfeducation and self-development of adult personality", Information Technologies in Education, № 24, pp. 172191, 2015. (in Ukrainian)

[20] H. A. Dehtiarova, "Formation the competence of information and communication technologies of teachersphilologists in the system of specialist's continuous education". [Online]. Available: http://tme.umo.edu.ua/docs/5/11degsue.pdf. Accessed on: Dec. 02, 2018. (in Ukrainian)

[21] O. B. Kyselyova, "Forming the self-educational competence of a future teacher in the conditions of informativeeducational environment", author's abstract. dis. cand. pedagogical sciences, H. S. Skovoroda Kharkiv National Pedagogical University, Kharkiv, Ukraine, 2011. (in Ukrainian) 
[22] M. Raspopovic, S. Cvetanovic, and A. Jankulovic, "Challenges of transitioning to e-learning system with learning objects capabilities", The International Review of Research in Open and Distributed Learning, vol. 17, no. 1, pp. 123-147, 2016. (in English)

[23] O. P Pinchuk, "Historical and analytical review of social networking technologies and prospects of their use in training", Information Technologies and Learning Tools, vol. 48, №4, pp.14-34, 2015. [Online]. Available: http://journal.iitta.gov.ua/index.php/itlt/article/view/1267/949 7. Accessed on: Dec. 02, 2018. (in Ukrainian)

Text of the article was accepted by Editorial Team 03.01.2019.

\title{
ВИКОРИСТАННЯ ІНФОРМАЦІЙНО-КОМУНІКАЦІЙНИХ ТЕХНОЛОГІЙ ДЛЯ ОРГАНІЗАЦІЇ САМООСВІТИ ОСОБИСТОСТІ В ГАЛУЗІ ДИЗАЙНУ ОДЯГУ
}

\author{
Пашкевич Калина Лівіанівна \\ доктор технічних наук, професор, професор кафедри ергономіки і проєктування одягу \\ Київський національний університет технологій та дизайну, м. Київ, Україна \\ ORCID ID 0000-0001-6760-3728 \\ pashkevich.kl@knutd.edu.ua
}

\section{Сжова Ольга Володимирівна}

доктор педагогічних наук, професор, професор кафедри теорії і методики технологічної підготовки, охорони праці та безпеки життєдіяльності

Центральноукраїнський державний педагогічний університет імені Володимира Винниченка,

м. Кропивницький, Україна

ORCID ID 0000-0002-5920-1611

oyezhova@gmail.com

\section{Герасименко Олена Дмитрівна}

аспірант кафедри ергономіки і проєктування одягу

Київський національний університет технологій та дизайну, м. Київ, Україна

ORCID ID 0000-0001-8566-7215

gerasymenko.od@knutd.edu.ua

\begin{abstract}
Анотація. У статті розглянуто особливості організації самоосвіти особистості 3 використанням інформаційно-комунікаційних технологій (IКT), а саме: інформаційні ресурси, які можуть стати основою для самоосвіти; організація навчання; способи закріплення отриманих знань, створення необхідних соціальних зв'язків. Визначено інформаційні ресурси, які можна використовувати для самоосвіти та надано їх класифікацію залежно від потреб особистості: для розширення світогляду або наукового пошуку. Серед них найбільш значущими є електронні бібліотеки та бібліографічні й реферативні бази даних. Проаналізовано способи організації самоосвітньої діяльності: масові онлайн курси, освітні додатки для ПК та мобільних телефонів, індивідуальні заняття (вебінари), послідовне самостійне освоєння окремих тем тощо. Розглянуто ІКТ, які сприяють створенню соціальних зв'язків і комунікації 3 колом однодумців та 3 вузькоспеціалізованими фахівцями (соціальні мережі, системи ідентифікації науковців, форуми та блоги). Надано приклади інформаційних ресурсів для отримання дизайнерами одягу професійно важливої інформації. Серед них блоги про мистецтво, моду та дизайн, сайти віртуальних музеїв, ресурси для діячів індустрії моди, сайти виставок, конкурсів, популярних та наукових журналів, дизайнерів та брендів. Визначено можливості оцінки достовірності наукової інформації з використанням бібліографічних і реферативних баз даних, соціальних мереж та індивідуальних профілів учених у системах ідентифікації. Для виявлення особливостей використання ІКТ було проведено анкетне опитування, яке показало основні інформаційні ресурси, що використовуються при пошуку необхідної інформації (енциклопедії і бази даних, соціальні мережі, YouTube канали та блоги в Twitter, LifeJournal тощо) та особливості її сприйняття. Встановлено, що ІКТ є основним джерелом для пошуку та отримання інформації.
\end{abstract}

Ключові слова: самоосвіта; інформаційно-комунікаційні технології (IКT); інформаційні ресурси; соціальні мережі; дизайн одягу. 


\title{
ИСПОЛЬЗОВАНИЕ ИНФОРМАЦИОННО-КОММУНИКАЦИОННЫХ ТЕХНОЛОГИЙ ДЛЯ ОРГАНИЗАЦИИ САМООБРАЗОВАНИЯ ЛИЧНОСТИ В ОБЛАСТИ ДИЗАЙНА ОДЕЖДЫ
}

\author{
Пашкевич Калина Ливиановна \\ доктор технических наук, профессор, профессор кафедры эргономики и проектирования одежды \\ Киевский национальный университет технологий и дизайна, г. Киев, Украина \\ ORCID ID 0000-0001-6760-3728 \\ pashkevich.kl@knutd.edu.ua

\section{Ежова Ольга Владимировна} \\ доктор педагогических наук, профессор, профессор кафедры теории и методики технологической \\ подготовки, охраны труда и безопасности жизнедеятельности \\ Центральноукраинский государственный педагогический университет имени Владимира Винниченко, \\ г. Кропивницкий, Украина \\ ORCID ID 0000-0002-5920-1611 \\ oyezhova@gmail.com
}

\section{Герасименко Елена Дмитриевна}

аспирант кафедры эргономики и проектирования одежды

Киевский национальный университет технологий и дизайна, г. Киев, Украина

ORCID ID 0000-0001-8566-7215

herasymenko.od@knutd.edu.ua

\begin{abstract}
Аннотация. В статье рассмотрены особенности организации самообразования личности с использованием информационно-коммуникационных технологий (ИКТ), а именно: информационные ресурсы, которые могут стать основой для самообразования; организация обучения; способы закрепления полученных знаний, создания необходимых социальных связей. Определены информационные ресурсы, которые можно использовать для самообразования и предоставлено их классификацию в зависимости от потребностей личности: для расширения кругозора или научного поиска. Среди них наиболее значимыми являются электронные библиотеки, библиографические и реферативные базы данных. Проанализированы способы организации самообразовательной деятельности: массовые онлайн-курсы, образовательные приложения для ПК и мобильных телефонов, индивидуальные занятия (вебинары), последовательное самостоятельное освоение отдельных тем и тому подобное. Рассмотрены ИКТ, способствующие созданию социальных связей и коммуникации с кругом единомышленников и с узкоспециализированными специалистами (социальные сети, системы идентификации ученых, форумы и блоги). Даны примеры информационных ресурсов для получения профессионально важной для дизайнеров одежды информации. Среди них блоги об искусстве, моде и дизайне, сайты виртуальных музеев, ресурсы для деятелей индустрии моды, сайты выставок, конкурсов, популярных и научных журналов, дизайнеров и брендов. Определены возможности оценки достоверности научной информации с использованием библиографических и реферативных баз данных, социальных сетей и индивидуальных профилей ученых в системах идентификации. Для выявления особенностей использования ИКТ был проведен анкетный опрос, который показал основные информационные ресурсы, используемые при поиске необходимой информации (энциклопедии и базы данных, социальные сети, YouTube каналы и блоги в Twitter, LifeJournal и т. д.) и особенности ее восприятия. Установлено, что ИКТ является основным источником для поиска и получения информации.
\end{abstract}

Ключевые слова: самообразование; информационно-коммуникационные технологии (ИКТ); информационные ресурсы; социальные сети; дизайн одежды.

\section{(cc)) BY-NC-SA}

This work is licensed under Creative Commons Attribution-NonCommercial-ShareAlike 4.0 International License. 